\title{
Globocephalus urosubulatus (Alessandrini, 1909) (Nematoda: Ancylostomatidae) in Brazil: a morphological revisitation
}

\author{
Globocephalus urosubulatus (Alessandrini, 1909) (Nematoda: Ancylostomatidae) \\ no Brasil: uma revisitação morfológica
}

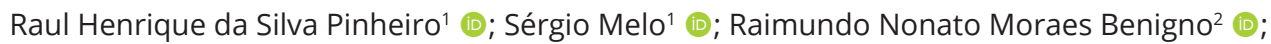 Elane Guerreiro Giese ${ }^{3 *}$ (1)

\author{
'Programa de Pós-graduação em Sociedade, Natureza e Desenvolvimento, Instituto de Biodiversidade e Florestas, \\ Universidade Federal do Oeste do Pará - UFOPA, Santarém, PA, Brasil \\ ${ }^{2}$ Laboratório de Parasitologia Animal, Instituto da Saúde e Produção Animal, Universidade Federal Rural da Amazônia - \\ UFRA, Belém, PA, Brasil \\ ${ }^{3}$ Laboratório de Histologia e Embriologia Animal, Instituto da Saúde e Produção Animal, Universidade Federal Rural da Amazônia - \\ UFRA, Belém, PA, Brasil
}

How to cite: Pinheiro RHS, Melo S, Benigno RNM, Giese EG. Globocephalus urosubulatus (Alessandrini, 1909) (Nematoda: Ancylostomatidae) in Brazil: a morphological revisitation. Braz J Vet Parasitol 2021; 30(3): e008120. https://doi.org/10.1590/ S1984-29612021078

\begin{abstract}
Helminthiasis occurs frequently in wild or domestic pigs in the most varied environments or production systems; however, the literature includes few taxonomic studies for the purpose of expanding this knowledge about the parasitic diversity in these animals. Thus, in order to expand this knowledge regarding parasitic diversity in these animals, the present study reports the occurrence and redescribes Globocephalus urosubulatus infecting domestic pigs in the state of Pará, Brazil, using microscopy. Four hundred and ten specimens of Sus scrofa intestinal nematodes were collected extensively in the municipality of Moju, northeastern mesoregion of Pará and observed under light and scanning electron microscopy. Based on morphological characteristics, the nematodes were identified as G. urosubulatus, and new morphological data were added by light microscopy and scanning electron microscopy for the diagnosis of this parasite.
\end{abstract}

Keywords: Biodiversity, nematodes, Sus scrofa, Pará, Amazon.

\begin{abstract}
Resumo
As helmintíases ocorrem frequentemente em porcos selvagens ou domésticos nos mais variados ambientes ou sistemas de produção, porém a literatura contempla poucos estudos taxonômicos. Assim, com a finalidade de ampliar esses conhecimentos sobre a diversidade parasitária nesses animais, o presente estudo relata a ocorrência e redescreve Globocephalus urosubulatus infectando porcos domésticos no estado do Pará, Brasil, utilizando-se microscopia. Foram recolhidos 410 exemplares de nematoides do intestino de Sus scrofa, criados extensivamente no município de Moju, mesorregião nordeste do Pará e observados em microscopia de luz e eletrônica de varredura. Com base em características morfológicas, os nematoides foram identificados como G. urosubulatus, sendo adicionados novos dados morfológicos por microscopia de luz e microscopia eletrônica de varredura para o diagnóstico desse parasito.
\end{abstract}

Palavras-chave: Biodiversidade, nematoides, Sus scrofa, Pará, Amazônia. 


\section{Introduction}

Helminthiasis frequently occurs in wild or domestic pigs in the most varied environments or production systems around the world, but has generally received less attention when compared to parasitological studies in ruminants (Thamsborg et al., 2017). For Hale \& Stewart (1979) and Roepstorff et al. (2011), helminth infections in these animals are not always apparent and persist at subclinical levels for extended periods, often leading to death for the animals.

Parasitism in pigs can affect performance in terms of efficient feeding, growth rate, general health and condemnation after slaughter (Weng et al., 2005). There are few studies that detail or inventory the parasitological fauna of wild and domestic species, especially in taxonomic assessments and that trace differences and similarities between different groups of parasites. Therefore, the accumulation of information over time will enable validation of the use of helminths in monitoring the health of ecosystems and pig breeding systems (Bongers \& Ferris, 1999; Brandão et al., 2009).

Due to the economic and ecological importance of pigs, especially those destined for slaughter, many researchers in different countries such as France (Humbert \& Henry, 1989), India (Yadav \& Tandon, 1989; Laha et al., 2014a, b), Tanzania (Esrony et al., 1997), Mexico (Ortega-Pierres et al., 2000), Croatia (Rajković-Janje et al., 2002), Iran (Solaymani-Mohammadi et al., 2003), Burkina Faso (Tamboura et al., 2006), Zimbabwe (Marufu et al., 2008), Kenya (Kagira et al., 2012), Ethiopia (Kumsa \& Kifle, 2014), Philippines (Padilla \& Ducusin, 2015), Azerbaijan (Ali Gyzy \& llyas Oglu, 2016), Bulgaria (Panayotova-Pencheva \& Dakova, 2018) and Colombia (Chaparro-Gutiérrez et al., 2018), have been studying their parasitic communities in order to get to know its parasitic community, as well as its relationship with public health and with the high rates of morbidity and mortality in different production systems.

Despite the Brazilian literature involving several studies on the parasitic fauna of pigs, these data are scarce for the Amazon region, mainly regarding helminth diversity in pigs raised extensively and not submitted to the hygienicsanitary inspection process. Among the nematodes present as fauna parasites in pigs in Brazil, the most genera most often recorded genera are Ascaris, Ascarops, Globocephalus, Hyostrongylus, Metastrongylus, Oesophagostomum, Physocephalus, Stephanurus, Strongyloides, Trichostrongylus and Trichuris (D'Alencar et al., 2006; Pinto et al., 2007; Brito et al., 2012; Anjos et al., 2015; Mattos et al., 2020).

The genus Globocephalus is one of the least known and is represented in Brazilian territory by two species $G$. urosubulatus (Alessandrini, 1909) and G. marsupialis Freitas \& Lent, 1936 (Vicente et al., 1997). Only G. urosubulatus has been recorded as parasitizing pigs in different rearing systems in Brazil (Freitas \& Costa, 1967; Francis, 1978; Carneiro et al., 1979, 1980; Pinto et al., 2007). Thus, the aim of the present study was to report the occurrence and redescribe Globocephalus urosubulatus infecting domestic pigs in the state of Pará, Brazil, using microscopic tools.

\section{Materials and Methods}

\section{Survey data}

The nematodes were recovered from the small intestine of a single pig slaughtered at a market in the municipality

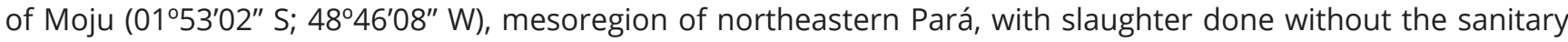
control. The intestine was placed in a basket and washed with water, and macro-residues were separated with the aid of a steel granulometric sieve $(9.50 \mathrm{~mm}$ opening). What passed through the sieve was then fixed in $70 \%$ ethanol, stored at room temperature according to (Ahn et al., 2015; Kuzmin et al., 2019; Morais et al., 2020) and transported in a $30 \mathrm{~L}$ bag to the Laboratório de Parasitologia Animal, Instituto da Saúde e Produção Animal, Universidade Federal Rural da Amazônia. Aliquots of the material were separated into petri dishes, observed with the aid of a stereomicroscope (LEICA-ES2) and the parasites collected.

\section{Light microscopy}

For morphological and morphometric analysis twenty-five nematodes ( 15 females, 10 males) were dehydrated in an ethanol series, clarified with Aman's Lactophenol (20\%) and observed using a light microscope, and LEICA DM2500 camera with an imaging capture system. Measurements are shown in micrometers as the mean followed by the range, or as otherwise indicated. Taxonomic classification of nematodes was in accordance with Cameron (1924), Freitas \& Lent (1936), Vicente et al. (1997) and Anderson et al. (2009). 


\section{Scanning electron microscopy}

For scanning electron microscopy (SEM), twenty nematodes (10 females and 10 males) were post-fixed in 1\% osmium tetroxide, dehydrated to the critical point for $\mathrm{CO}_{2}$, metalized with gold-palladium, and analyzed with the VEGA 3 LMU/TESCAN scanning electron microscope at the Laboratório de Microscopia Eletrônica de Varredura, Instituto de Saúde e Produção Animal da Universidade Federal Rural da Amazônia.

\section{Results}

A total of 410 [females $=264$, males $=146$ ] nematodes were recovered from Sus scrofa. All specimens collected showed characteristics compatible with the genus Globocephalus (Nematoda: Ancylostomatidae). The morphological and morphometric characteristics of the nematodes recovered from domestic pigs are presented below and in Table 1.

Table 1. Morphological and morphometric comparison of Globocephalus urosubulatus collected in Sus scrofa from State of Pará, Brazil.

\begin{tabular}{|c|c|c|c|c|c|c|c|c|}
\hline \multirow{2}{*}{ Character } & \multicolumn{2}{|c|}{$\begin{array}{l}\text { Globocephalus } \\
\text { urosubulatus }\end{array}$} & \multicolumn{2}{|c|}{ G. urosubulatus } & \multicolumn{2}{|c|}{ G. urosubulatus } & \multicolumn{2}{|c|}{$\begin{array}{c}\text { Globocephalus } \\
\text { marsupialis }\end{array}$} \\
\hline & Male & Famele & Male & Female & Male & Famale & Male & Famale \\
\hline Hosts Type locality & \multicolumn{2}{|c|}{ Sus scrofa Moju-Pará } & \multicolumn{2}{|c|}{$\begin{array}{c}\text { Sus scrofa Rio de } \\
\text { Janeiro }\end{array}$} & \multicolumn{2}{|c|}{ Sus scrofa Bulgaria } & \multicolumn{2}{|c|}{$\begin{array}{l}\text { Metachirops opossum } \\
\text { Petrópolis-Rio de } \\
\text { Janeiro }\end{array}$} \\
\hline Length $(\mathrm{mm})^{\mathrm{a}}$ & 4-5 & $6-8$ & $3.16-5.32$ & $5.02-6.53$ & $3.5-5$ & $4.5-8$ & $4.4-6.18$ & $10.47-11.44$ \\
\hline Width & $167-300$ & 429-514 & $320-400$ & $490-570$ & $360-370$ & $420-500$ & $237-316$ & $400-430$ \\
\hline Buccal capsule ${ }^{b, L}$ & $125-150$ & $167-227$ & $119-127$ & $192-220$ & $140-200$ & $140-200$ & 104 & $129-143$ \\
\hline Buccal capsule ${ }^{b, w}$ & $100-140$ & $140-160$ & $162-186$ & $159-178$ & $150-170$ & $150-170$ & 96 & $114-129$ \\
\hline Nerve ring & $317-367$ & $387-500$ & $290-460$ & $380-460$ & $380-520$ & $380-520$ & 360 & 429 \\
\hline Excretory pore & $317-417$ & 433-547 & $320-500$ & $320-530$ & - & - & - & - \\
\hline Deirids & $370-533$ & 433-547 & - & - & $430-610$ & $430-610$ & - & - \\
\hline Muscular esophagus ${ }^{a, b, L}$ & $0.487-0.540$ & $0.593-0.687$ & $0.550-0.710$ & $0.680-0.75$ & $0.560-0.690$ & $0.560-0.690$ & $0.789-0.800$ & $1-1.3$ \\
\hline Muscular esophagus b, w & $93-133$ & 147-173 & $110-170$ & $110-160$ & $120-150$ & $120-150$ & - & - \\
\hline Vulva (mm) & - & 3-5 & - & $1.73-2.91$ & - & $2.20-2.40^{c}$ & - & 4.4-5.7 \\
\hline Spicule & $337-527$ & - & $490-550$ & - & $420-580$ & - & $338-378$ & - \\
\hline Gubernaculum & $60-88$ & - & $89-110$ & - & $70-80$ & - & $38-48$ & - \\
\hline Tail & - & $130-200$ & - & - & $120-180$ & $120-180$ & - & $304-329$ \\
\hline Mucron & \multicolumn{2}{|c|}{ Absent } & \multicolumn{2}{|c|}{ - } & - & 40 & \multicolumn{2}{|c|}{-} \\
\hline Reference & \multicolumn{2}{|c|}{ From this study } & \multicolumn{2}{|c|}{ Francis (1978) } & \multicolumn{2}{|c|}{ Nanev et al. (2007) } & \multicolumn{2}{|c|}{ Freitas \& Lent (1936) } \\
\hline
\end{tabular}

aMeasurements in micrometers unless indicated and the parameter number of buds is given in amplitude; bAbbreviations: L: length, W: width; 'Distance between the vulva and the posterior body end.

Ancylostomatidae Looss, 1905

Globocephalus Molin, 1861

Globocephalus urosubulatus (Alessandrini, 1909)

(Based on light microscopy and scanning electron microscopy examination: Figures 1-3)

Medium size nematode. Females larger than males, the morphology of the anterior region being similar in both sexes (Figures 1a, b, 3a). Thick cuticle, with thin transverse streaks along the body. Long, rounded cephalic end, circular mouth opening, surrounded by a delicate cuticular ring (Figure 1c, 3b). Subglobular buccal capsule, without cutting plates or teeth on its margin, a pair of large sub-ventral teeth near the base of the capsule (Figure 1d). A rib with small spines reaching the top of the inner surface of the mouth capsule on its back (Figure 3c). Four external cephalic papillae and four internal papillae and a pair of lateral amphids. Well-developed claviform muscular esophagus, opening to the intestine through a strong valve. Excretory pore and spoon-shaped deirids located near the nerve ring (Figures 1a, b, 3a).

Females with eggs (based on 10 specimens): body $6 \mathrm{~mm}(6-8 \mathrm{~mm})$, maximum width at esophageal/intestinal junction $469 \mu \mathrm{m}(429-517 \mu \mathrm{m})$. Length of buccal capsule $200 \mu \mathrm{m}(167-227 \mu \mathrm{m}) \times 148 \mu \mathrm{m}(140-160 \mu \mathrm{m})$. Maximum length/ 
width ratio of buccal capsule 1:0.7. Muscular esophagus with a size of $645 \mu \mathrm{m}(593-687 \mu \mathrm{m}) \times 157 \mu \mathrm{m}(147-173 \mu \mathrm{m})$. The esophagus represents $10 \%$ (8-11\%) of body length. Length of entire esophagus and buccal capsule representing $13 \%(11-14 \%)$ of body length. Nerve ring, excretory pore and deirids at $452 \mu \mathrm{m}(387-500 \mu \mathrm{m}), 482 \mu \mathrm{m}(433-547 \mu \mathrm{m})$ and $495 \mu \mathrm{m}(433-547 \mu \mathrm{m})$, respectively, from anterior extremity. Vulva situated at, $4 \mathrm{~mm}(3-5 \mathrm{~mm})$ from anterior end, at about 63\% (59-67\%) of body length; vulval lips not elevated (Figure 1e, 3d). Muscular vagina directed posteriorly; uterus filled with eggs elliptical or round shape, shell single, thin, smooth and transparent and morulated embryo (Figure $1 \mathrm{~g})$. The eggs have a size of $49 \mu \mathrm{m}(32-67 \mu \mathrm{m})$ long by $32 \mu \mathrm{m}(23-47 \mu \mathrm{m})$ wide. Tail conical has a length of $162 \mu \mathrm{m}$ $(130-200 \mu \mathrm{m})$ (Figure 1f), with two small papillae near the end (Figure 3e). Anus with prominent upper lip (Figure 3e).
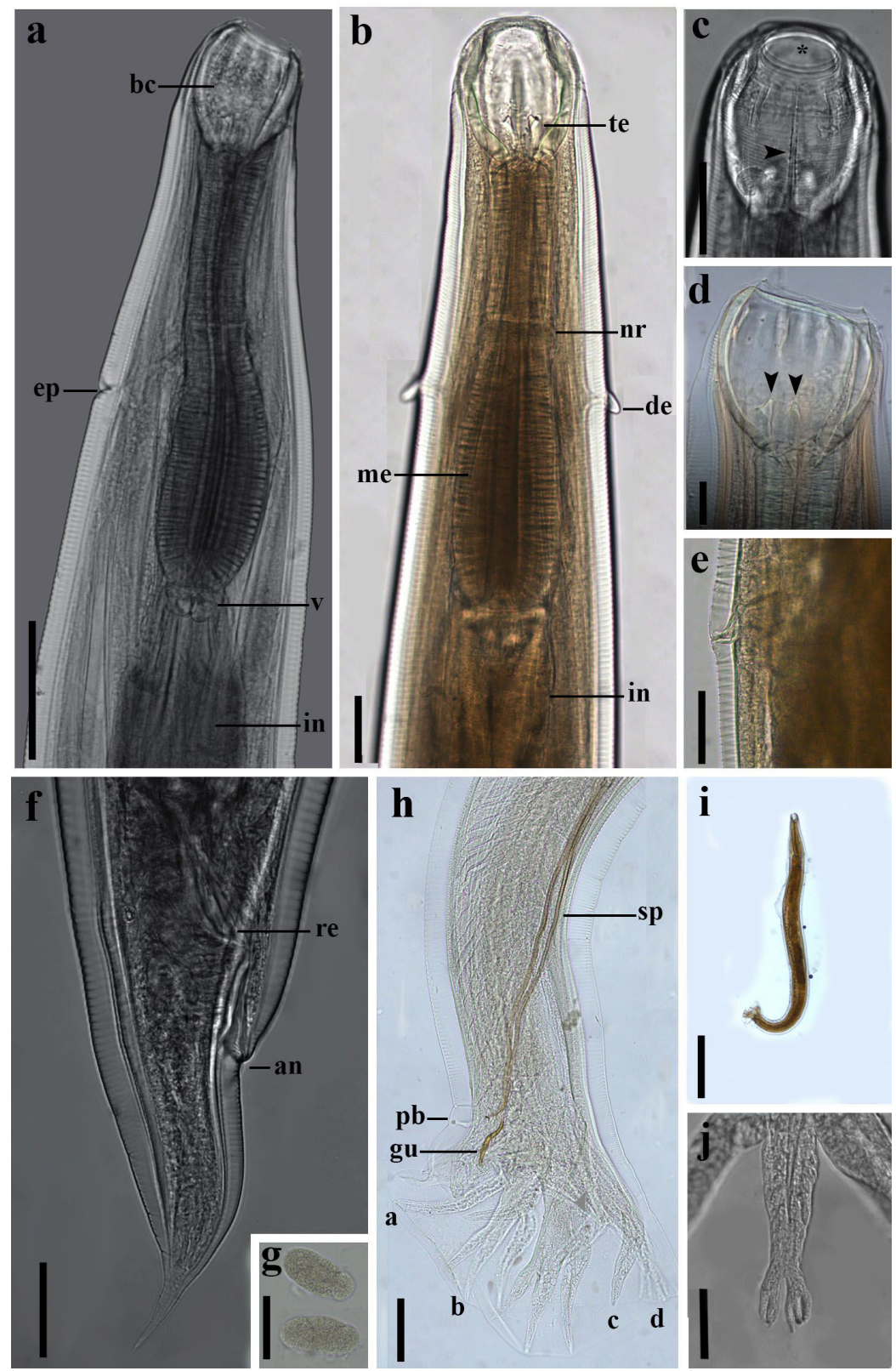

i

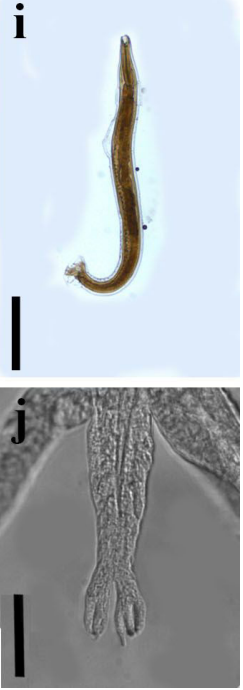

Figure 1. Light microscopy of Globocephalus urosubulatus: (a) Lateral view of cephalic region of female showing buccal capsule (bc); excretory pore (ep); posterior region of the esophagus is expanded and opens into the intestine by a strong valve ( $v$ ) and intestine (in). Bar = 200 $\mu \mathrm{m}$; (b)Ventral view of cephalic region showing buccal capsule; teeth (te); nerve ring (nr); deirids (de); muscular esophagus (me) and intestine (in). Bar $=100 \mu \mathrm{m}$; (c) Detail of circular oral opening $\left(^{*}\right)$ and rib with small spines reaching the inside tip of the buccal capsule on the back (arrow points). Bar $=100 \mu \mathrm{m}$; (d) buccal capsule armed with two sclerotized tooth-like structures (arrow points). Bar $=50 \mu \mathrm{m}$; (e) Detail of vulva. Bar $=100 \mu \mathrm{m}$; (f) Posterior end of female lateral view: rectum (re) and anus (an). Bar = $50 \mu \mathrm{m}$; (g) Detail of eggs. Bar = 50 $\mathrm{mm}$; (h) Posterior end of male, lateral view spicules (sp); pre-bursal papillae (pb); Gubernaculum (gu) and papillae $a=$ ventral and lateroventral rays, $b=$ anterolateral, mediolateral, posterolateral rays, $c=$ externodorsal rays and $d=$ dorsal trunk. Bar $=100 \mu \mathrm{m}$; (i) Overview of a male specimen. Bar $=12 \mu \mathrm{m}$; $(\mathbf{j})$ Detail of the trifurcated final part of the dorsal trunk. Bar $=50 \mu \mathrm{m}$. 


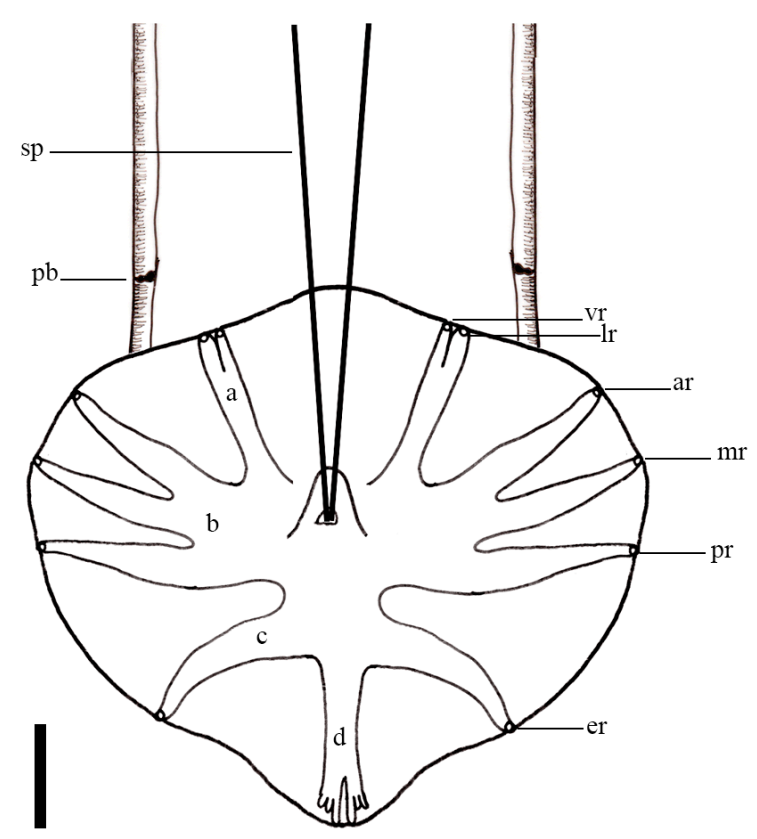

Figure 2. Light microscopy of Globocephalus urosubulatus in ventral view of the caudal bursa showing the spicules (sp); pre-bursal papillae (pb) and papillae $a=$ ventroventral (vr) and lateroventral rays (Ir), b = anterolateral (ar) mediolateral (mr), posterolateral rays (pr), $c=$ externodorsal rays (er) and $d=$ dorsal trunk. Bar $=100 \mu \mathrm{m}$.

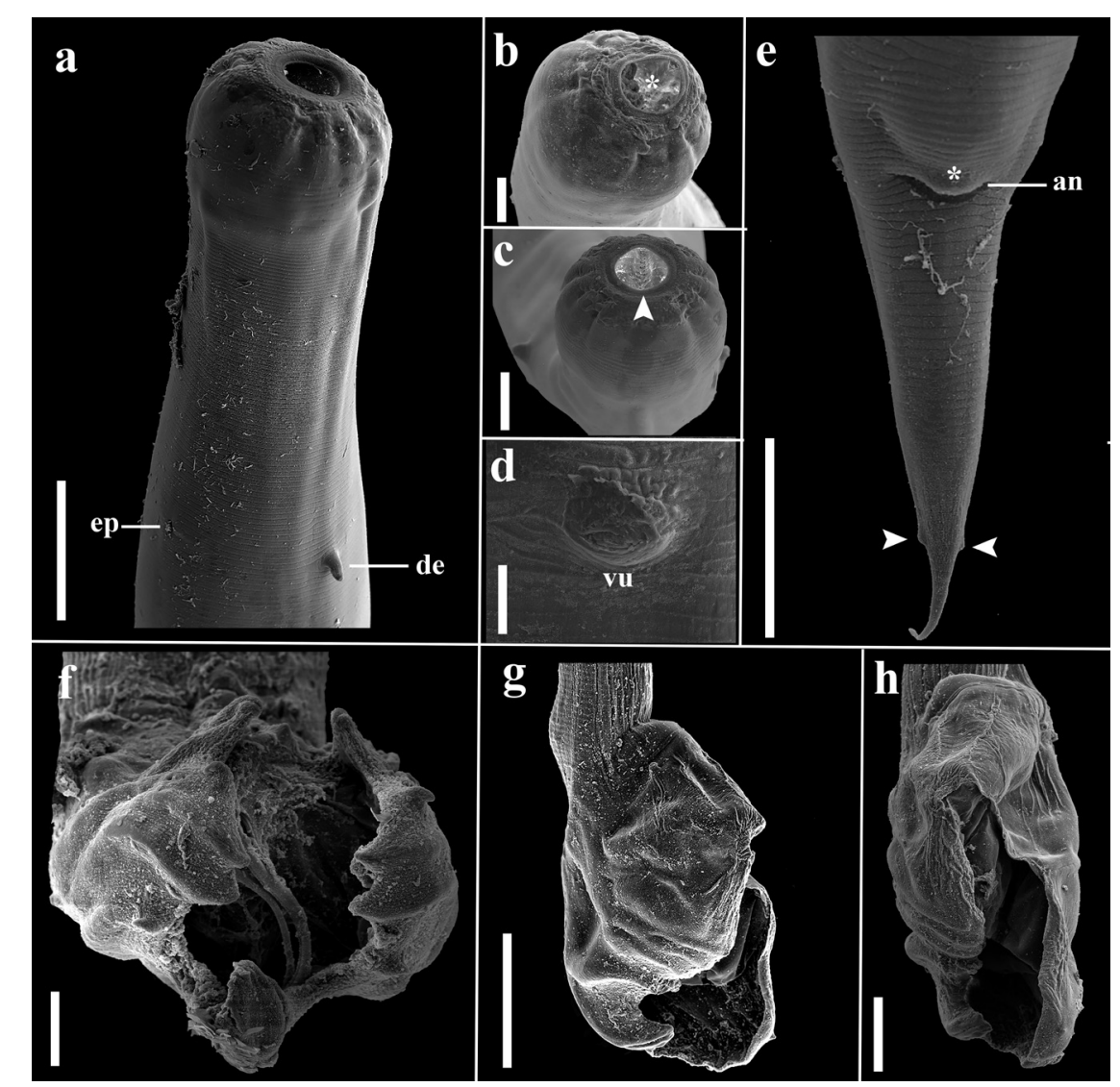

Figure 3. Scanning electron microscopy of Globocephalus urosubulatus. (a) Lateral view of cephalic region of female showing circular oral opening, excretory pore (ep) and deirid (de). Bar $=100 \mu \mathrm{m}$; (b) Frontal view of the oral opening $(*)$ of males. Bar $=$ $20 \mu \mathrm{m}$; (c) View of the rib with small spines reaching the inside tip of the buccal capsule on the back. Bar $=50 \mu \mathrm{m}$; (d) Detail of

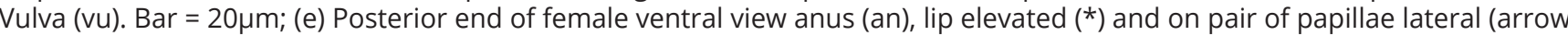
points). Bar $=50 \mu \mathrm{m} ;(\mathrm{f}, \mathrm{g}, \mathrm{h}$ ) Different views of the male caudal region. Bar $=20 \mu \mathrm{m}, \mathrm{Bar}=100 \mu \mathrm{m}, \mathrm{Bar}=50 \mu \mathrm{m}$. 
Females without eggs (based on 5 specimens): body $6 \mathrm{~mm}(4-8 \mathrm{~mm})$ long, maximum

width at esophageal/intestinal junction $474 \mu \mathrm{m}(457-514 \mu \mathrm{m})$. Length of buccal capsule $209 \mu \mathrm{m}(193-227 \mu \mathrm{m})$ $\times 151 \mu \mathrm{m}(140-160 \mu \mathrm{m})$. Maximum length/width ratio of buccal capsule 1:0.7. Muscular esophagus with a size of $512 \mu \mathrm{m}(487-540 \mu \mathrm{m}) \times 116 \mu \mathrm{m}(93-133 \mu \mathrm{m})$. The esophagus represents $10 \%(8-11 \%)$ of body length. Length of entire esophagus and buccal capsule representing 13\% (11-15\%) of body length. Nerve ring, excretory pore and deirids at $476 \mu \mathrm{m}(447-500 \mu \mathrm{m}), 488 \mu \mathrm{m}(447-547 \mu \mathrm{m})$ and $512 \mu \mathrm{m}(480-573 \mu \mathrm{m})$, respectively, from anterior extremity. Vulva situated at, $4 \mathrm{~mm}$ (3-5mm) from anterior end, at about $64 \%$ (60-69\%) of body length; vulval lips not elevated. Muscular vagina directed posteriorly, uterus without eggs. Tail conical has a length of $150 \mu \mathrm{m}(143-157 \mu \mathrm{m})$, with two small papillae near the end. Anus with prominent upper lip.

Males (based on 10 specimens): body $5 \mathrm{~mm}(4-5 \mathrm{~mm})$, maximum width at esophageal/intestinal junction $260 \mu \mathrm{m}$ $(167-300 \mu \mathrm{m})$. Length of buccal capsule $132 \mu \mathrm{m}(125-150 \mu \mathrm{m}) \times 111 \mu \mathrm{m}(100-140 \mu \mathrm{m})$. Maximum length/width ratio of buccal capsule 1:0.8. Muscular esophagus with a size of $512 \mu \mathrm{m}(487-540 \mu \mathrm{m}) \times 116 \mu \mathrm{m}(93-133 \mu \mathrm{m})$. The esophagus represents $11 \%(10-13 \%)$ of the total body length. Length of entire esophagus and buccal capsule representing $14 \%(12-16 \%)$ of body length. Nerve ring, excretory pore and deirids at $347 \mu \mathrm{m}(317-367 \mu \mathrm{m}), 369 \mu \mathrm{m}(317-417 \mu \mathrm{m})$ and $456 \mu \mathrm{m}(370-533 \mu \mathrm{m})$, respectively, from anterior extremity. Spicules long, filiform, sub-equal and sclerotized $437 \mu \mathrm{m}(337-527 \mu \mathrm{m})$ long, representing $9 \%(7-11 \%)$ of total body length. The parasite had dorsally curved and sometimes S-shaped points. Spoon-shaped sclerotized gubernaculum sclerotized in lateral view, with a length of $76 \mu \mathrm{m}(60-88 \mu \mathrm{m})$. One pair of pre-bursal papillae present. Copulatory bursa well developed (Figures 3f, g, h), broader than long, supported by five rays emerging from a dorsal trunk: thick dorsal trunk, bifurcated from two thirds of the length, of which each sub-ray is trifurcated at the end (Figures $1 \mathrm{~h}, \mathrm{i}, 2$ ). Bifurcated first arched rays (ventroventral and lateroventral), three slender and arched lateral rays with a common rod. The anterolateral, mediolateral and posterolateral rays merge at the base and then divide, projecting in parallel, to the edge of the bursa (Figure 1j). The externodorsal rays emerge from the trunk and project parallel to the edge of the bursa.

\section{Discussion}

The nematodes parasitizing the intestines of pigs, collected in the municipality of Moju, state of Pará, have similar characteristics to those of other species of the family Ancylostomatidae (Looss, 1905) and genus Globocephalus (Molin, 1861). Based on these morphological features, the nematodes were identified as G. urosubulatus (Alessandrini, 1909). Taxonomically the genus Globocephalus has undergone different classification proposals: Cystocephalus Railliet (1895), Characostomum Railliet (1902), Crassisoma Alessandrini (1909), Raillietostrongylus (Lane, 1923) and Glococephaloides (Yorke \& Maplestone, 1926), but today the denomination Globocephalus is accepted under the rules of zoological nomenclature.

Worldwide, there are few species proposed for Globocephalus and its well-defined biogeographic distributions: G. longemucronatus Molin, 1861 (Germany and Japan), G. connorfilii Lane 1922 (India, Samoa, China and Taiwan), G. samoensis (Lane, 1922) (Samoa, New Guinea, India, China and Japan), G. sichuanensis Wu 1984 (China), G. amucronatus (Smit \& Notosoediro, 1926) (Netherland), G. versteri Ortlepp, 1964 (Africa), G. madagascariensis Chanaid 1966 (Madagascar), G. urosubulatus (Alessandrini, 1909) (Austria, turkey, New Zealand, French, Germany, Bulgaria, Zaire, Iran, Guyana, Africa, New Guinea, India and America) (Ahn et al., 2015) and G. marsupialis Freitas \& Lent, 1936 (America), the last two being recorded in Brazil (Vicente et al., 1997). G. marsupialis the latter being described as a parasite of the small intestine of Philander opossum (Linnaeus, 1758) (Syn. Metachirops opossum) (Mammalia: Didelphidae) in the State of Rio de Janeiro.

There are few taxonomic studies for the genus Globocephalus. Even the original descriptive articles have limitations in their morphological and morphometric data, which makes it necessary to update these data again (Lane, 1922; Cameron, 1924; Freitas \& Lent, 1936), as in studies by Nanev et al. (2007) for G. urosubulatus collected from wild boars in Bulgaria and Ahn et al. (2015) to provide morphological features, and measurements of various parts of the adult nematodes by both light and scanning electron microscopies from G. samoensis in wild boars from South Korea.

This is the first study to describe ultrastructural aspects of G. urosubulatus in Brazil, in the world most studies for this species were based on ligth microscopy, but in this study the use of SEM made it possible to observe the mouth opening, distribution of cephalic papillae, deirids, vulva and a panorama of the male's tail, in addition to the presence of a pair of papillae present in the female's tail. According to Cesaroni et al. (2017) nematodes are small and usually have small external morphological characters, although the use of SEM has been used in taxonomic 
and systematic publications for helminths, its use for large groups such as nematodes this technique is still limited, even if it allows for observation of details that light microscopy hardly detects.

In this study we present new morphological and morphometric data and the first record of G. urosubulatus recovered from pigs in the State of Pará. Different authors have reported the presence of this parasite in the same host in Brazil: Amazonas (Freitas \& Costa, 1967), Goiânia and Distrito Federal (Carneiro et al., 1979, 1980), Rio de Janeiro (Francis, 1978) and Bahia (Pinto et al., 2007).

Species of Globocephalus are taxonomically characterized by the morphology and morphometry of the oral capsule, teeth, position of the vulva and the distribution of rays in the male copulatory bursa, as well as the morphology of the dorsal ray (Freitas \& Lent, 1936; Ahn et al., 2015). For Nanev et al. (2007) characteristics such as body size, esophagus, nerve ring, length of specimens and gubernaculum used independently as taxonomic criteria for species identification are not reliable.

Based on these morphological features, the nematodes were identified as Globocephalus urosubulatus. In Brazil, only Francis (1978) presented morphometric data for this species recovered from the intestine of pigs in the state of Rio de Janeiro, the morphometry being very similar to this study, with only differences in the location of the vulva in females (3-5mm), while that for the specimens found in Rio de Janeiro, the location was closer to the cephalic region (1.73-2.91 mm), which can also be observed in the study by Nanev et al. (2007) for female specimens of G. urosubulatus $(2.20-2.40 \mathrm{~mm})$ in pigs in Bulgaria. However, the use of young females can justify such variation, which in this work we have resolved by presenting the morphometry of ovigerous females and juvenile females separately.

Globocephalus urosubulatus differs from G. marsupialis, in addition to the host group, in morphology and morphometry, especially the gubernaculum (G. urosubulatus $=60-88 \mu \mathrm{m} \times G$. marsupialis $=38-48 \mu \mathrm{m}$ ) and spicules (G. urosubulatus $=337-527 \mu \mathrm{m} \times$ G. marsupialis $=338-378 \mu \mathrm{m}$ ), in addition to the size of the female esophagus and tail. For Freitas \& Lent (1936), although the genus Globocephalus presents a small number of species, it presents difficulties regarding the literature described for the genus, especially due to the impossibility of studying the species, since Molin drawings have weak taxonomic arguments, which would hardly support the species distinction. Morphological and morphometric data for G. urosubulatus and G. marsupialis are presented in Table 1.

Morphologically the $G$. urosubulatus eggs observed in the womb presented an elliptical or round shape, shell single, thin, smooth and transparent and morulated embryo. Even though the description of the eggs of this species is presented, we do not believe that it is a strong character for differentiation or diagnosis of this parasite, since egg morphology is very similar to that of other species within the Ancylostomatidae. So far, no coprological diagnosis of G. urosubulatus has been made in Brazil, with most of the positive specimens obtained from necropsies (see Freitas \& Costa, 1967; Francis, 1978; Carneiro et al. 1979, 1980; Vicente et al., 1997; Pinto et al., 2007). However, the records of occurrence and prevalence of $G$. urosubulatus by coprological examinations are also few in the literature: Permin et al. (1999) registered in Ghana (2.7\% for eggs and 20\% for adults after necroscopic examination); Dadas et al. (2016) in Mumbai demonstrated low prevalence $(0.74 \%)$ of parasitism. Nwoha \& Ekwurike (2011) registered in Abia State (Nigeria) $68 \%$ of the eggs of Globocephalus sp. in fecal samples from pigs of different ages. Stojanov et al. (2018) registered a prevalence of $30 \%$ of Globocephalu sp. in pigs in Serbia. Pinto et al. (2007) emphasize the importance of nematodes rarely reported in the parasite of pigs literature, especially in Brazil, and they use G. urosubulatus as an example, emphasizing that the conditions of the reproduction environment, especially the free-living ones, favor the maintenance of the parasites in the cycle.

Nejsum et al. (2012), states that in addition to the close similarity in the morphology of eggs of different species present and the same host, cases of cross-infection would not be detected by standard coprology methods, and mentions that studies based only on coprological exams, for example, may be the reason that the zoonotic potential of certain nematodes such as $T$. suis has been ignored so far.

\section{Conclusion}

This study describes the occurrence of Globocephalus urosubulatus adding data in light microscopy and scanning electron microscope, in addition to expanding the knowledge about this species and contributing to a better understanding of the diversity of nematodes in pigs in Brazil. 


\section{Acknowledgements}

The authors are grateful to the following the Laboratório de Histologia e Embriologia Animal and Laboratório de Microscopia Eletrônica de Varredura - Instituto da Saúde e Produção Animal - Universidade Federal Rural da Amazônia - UFRA, campus Belém, state of Pará, Brazil for the use of the scanning electron microscope. Raul Henrique da Silva Pinheiro was supported by a research fellowship from the "Programa de Pós-Graduação em Sociedade, Natureza e Desenvolvimento (PPGSND), Universidade Federal do Oeste do Pará - UFOPA/ CAPES/ BRASIL) - Finance Code 001". Dra. Elane Giese was supported by a researcher fellowship of Conselho Nacional de Pesquisa e Desenvolvimento Tecnológico (CNPq-Brasil) (\#313763/2020-8).

\section{References}

Ahn KS, Ahn AJ, Kim TH, Suh GH, Joo KW, Shin SS. Identification and Prevalence of Globocephalus samoensis (Nematoda: Ancylostomatidae) among Wild Boars (Sus scrofa coreanus) from Southwestern Regions of Korea. Korean J Parasitol 2015; 53(5): 611-618. http://dx.doi.org/10.3347/kjp.2015.53.5.611. PMid:26537041.

Ali Gyzy HN, llyas Oglu AE. Intestinal parasites in domestic pigs (Sus scrofa domesticus) in farms of Azerbaijan.J Entomol Zool Stud 2016; 4(3): 170-173.

Anderson RC, Chabaud AG, Willmott S. Keys to the nematode parasites of vertebrates: archival volume. Wallingford: CABI International; 2009. http://dx.doi.org /10.1079/9781845935726.0000.

Anjos GSA, Benigno RNM, Serra-Freire NM. Patologia da estefanurose em suínos de produção artesanal no município de Cachoeira do Arari, Ilha de Marajó - Estado do Pará - Brasil. Rev UNIABEU 2015; 8(20): 311-324.

Bongers T, Ferris H. Nematode community structure as a bioindicator in environmental monitoring. Trends Ecol Evol 1999; 14(6): 224-228. http://dx.doi.org/10.1016/S0169-5347(98)01583-3. PMid:10354624.

Brandão ML, Chame M, Cordeiro JLP, Chaves SAM. Diversidade de helmintos intestinais em mamíferos silvestres e domésticos na Caatinga do Parque Nacional Serra da Capivara, Sudeste do Piauí, Brasil. Rev Bras Parasitol Vet 2009;18(Suppl. 1): 19-28. http:// dx.doi.org/10.4322/rbpv.018e1004. PMid:20040186.

Brito GG, Santos TB, De Melo CM, Jeraldo VLS. Ocorrência de enteroparasitas em amostras fecais de suínos do município de Simão Dias/SE. Cad Grad. Ciênc Biol Saúde 2012; 1(15): 11-18.

Cameron TWM. On the nematode genus Globocephalus Molin, 1861.J Helminthol 1924; 2(2): 65-76. http://dx.doi.org/10.1017/ S0022149X00003035.

Carneiro JR, Pereira E, Lustosa ÉS, Campos DMB. Helmintos gastrintestinais de suínos no município de Goiânia. Rev Patol Trop 1979; 8(3-4): 135-136. http://dx.doi.org/10.5216/rpt.v8i3\%20e\%204.21384.

Carneiro JR, Pereira E, Martins W Jr, Freitas MG. Contribuição para o estudo do diagnóstico de Leucemia bovina. Lista de helmintos parasitos de animais domésticos do Estado de Goiás. Rev Patol Trop 1980; 9(1-2): 61-71. https://doi.org/10.5216/rpt. v9i1\%20e\%202.21346.

Cesaroni L, Guidi L, Balsamo M, Semprucci F. Scanning electron microscopy in the taxonomical study of free-living marine nematodes. Microscopie 2017; 28(2): 31-38. http://dx.doi.org/10.4081/microscopie.2017.6970.

Chaparro-Gutiérrez JJ, Pozio E, Gómez-Morales MA, López A, Mejia J, Zambrano C, et al. A preliminary survey of Trichinella spp. in pigs raised under controlled housing conditions in Colombia: 2014-2016. Parasite 2018; 25: 18. http://dx.doi.org/10.1051/ parasite/2018023. PMid:29633706.

D'Alencar AS, Faustino MAG, Sousa DP, Lima MM, Alves LC. Infecção por helmintos e coccídios em criação de suínos de sistema confinado localizada no município de Camaragibe-PE. Ciênc Vet Tróp 2006; 9(2-3): 79-86.

Dadas S, Mishra S, Jawalagatti V, Gupta S, Vinay TS, Gudewar J. Prevalence of gastro-intestinal parasites in pigs (Sus scrofa) of Mumbai Region. Int J Sci Environ Technol 2016; 5(2): 822-826.

Esrony K, Kambarage DM, Mtambo MMA, Muhairwa AP, Kusiluka LJM. Helminthosis in local and cross-bred pigs in the Morogoro region of Tanzania. Prev Vet Med 1997; 32(1-2): 41-46. http://dx.doi.org/10.1016/S0167-5877(97)00011-1. PMid:9361319.

Francis M. Estudo da helmintofauna de Sus scrofa L., 1758 no Estado do Rio de Janeiro - Brasil [dissertation]. Rio de Janeiro: Universidade Federal Rural do Rio de Janeiro; 1978.

Freitas JFT, Lent H. Estudo sobre o genero Globocephalus Molin, 1861 (Nematoda: strongyloidea). Mem Inst Oswaldo Cruz 1936; 31(1): 69-79. http://dx.doi.org/10.1590/S0074-02761936000100004.

Freitas MG, Costa HMA. Pesquisa sobre helmintos e artrópodes parasitos de animais domésticos no Baixo Amazonas. In: Lent H, editor. Atas do Simpósio sobre a Biota Amazônica. Rio de Janeiro: Conselho Nacional de Pesquisas; 1967. p. 103-112. 
Hale OM, Stewart TB. Influence of an experimental infection of Trichuris suis on performance of pigs. J Anim Sci 1979; 49(4): 1000-1005. http://dx.doi.org/10.2527/jas1979.4941000x. PMid:541282.

Humbert JF, Henry C. Studies on the prevalence and the transmission of lung and stomach nematodes of the wild boar (Sus scrofa) in France. J Wildl Dis 1989; 25(3): 335-341. http://dx.doi.org/10.7589/0090-3558-25.3.335. PMid:2788229.

Kagira JM, Kanyari PN, Githigia SM, Maingi N, Nganga JC, Gachohi JM. Risk factors associated with occurrence of nematodes in free range pigs in Busia District Kenya. Trop Anim Health Prod 2012; 44(3): 657-664. http://dx.doi.org/10.1007/s11250-011-99519. PMid:21833678.

Kumsa B, Kifle E. Internal parasites and health management of pigs in Burayu District, Oromia Regional State, Ethiopia. J S Afr Vet Assoc 2014; 85(1): 913. http://dx.doi.org/10.4102/jsava.v85i1.913. PMid:24831203.

Kuzmin Y, Tkach VV, Melo FTV. Description, molecular characterization and life cycle of Serpentirhabdias mussuranae n. sp. (Nematoda: Rhabdiasidae) from Clelia clelia (Reptilia: Colubroidea) in Brazil.J Helmintho/ 2019; 94: e55. http://dx.doi.org/10.1017/ S0022149X19000348. PMid:31203823.

Laha R, Das M, Goswami A, Sailo B, Sharma BK, Gangmei D, et al. Prevalence of gastrointestinal parasitic infections in pigs of North Eastern Region of India. Indian J Hill Farming 2014a; 27(1): 64-67.

Laha R, Das M, Goswami A, Sen A, Suresh Kumar G. Kadirvel. Epidemiology of gastrointestinal parasitism in pigs in subtropical Hill Zone of Meghalaya. Indian J Hill Farming 2014b; 27(1): 59-63.

Lane C. A preliminary note on two Strongylata from swine in the Pacific. Ann Mag Nat Hist 1922; 9(9): 683-685. http://dx.doi. org/10.1080/00222932208632732.

Marufu MC, Chanayiwa P, Chimonyo M, Bhebhe E. Prevalence of gastrointestinal nematodes in Mukota pigs in a communal area of Zimbabwe. Afr J Agric Res 2008; 3(2): 91-95.

Mattos MJT, Marques ST, Juffo E, Ramos M, Silveira E, Ribeiro VLS. Parasitoses in family breeding pigs in the metropolitan region of Porto Alegre, RS, Brazil. Rev Agr Acad 2020; 3(1): 122-130. http://dx.doi.org/10.32406/v3n1/2020/122-129/agrariacad.

Morais DH, Müller MI, Melo FTV, Aguiar A, Willkens Y, de Sousa Silva C, et al. A new species of Rhabdias (Nematoda: Rhabdiasidae), a lung parasite of Pseudopaludicola pocoto (Anura: Leptodactylidae) from north-eastern Brazil: description and phylogenetic analyses. J Helmintho/ 2020; 94: e209. http://dx.doi.org/10.1017/S0022149X20000929. PMid:33138887.

Nanev V, Mutafova T, Todev I, Hrusanov D, Radev V. Morphological characteristics of Nematodes of the Globocephalus genus prevalent among wild boars from various regions of Bulgaria. Bulg J Vet Med 2007; 10(2): 103-111.

Nejsum P, Betson M, Bendall R, Thamsborg S, Stothard J. Assessing the zoonotic potential of Ascaris suum and Trichuris suis: looking to the future from an analysis of the past. J Helminthol 2012; 86(2): 148-155. http://dx.doi.org/10.1017/S0022149X12000193. PMid:22423595.

Nwoha RIO, Ekwurike JO. Prevalence of gastrointestinal nematode parasites in intensively managed pigs of different ages and sexes in Umuahia city of Abia State. Int Res J Biochem Bioinform 2011; 1(6): 161-167.

Ortega-Pierres MG, Arriaga C, Yépez-Mulia L. Epidemiology of trichinellosis in Mexico, Central and South America. Vet Parasitol 2000; 93(3-4): 201-225. http://dx.doi.org/10.1016/S0304-4017(00)00342-3. PMid:11099838.

Padilla MA, Ducusin RJT. Herd-level Prevalence and factors for risk of endoparasite infection in smallholder pig farms in Sariaya, Quezon, Philippines. Philipp J Vet Med 2015; 52(2): 99-106.

Panayotova-Pencheva M, Dakova V. Studies on the gastrointestinal and lung parasite fauna of wild boars (Sus scrofa scrofa L.) from Bulgaria. Ann Parasitol 2018; 64(4): 379-384. http://dx.doi.org/10.17420/ap6404.174. PMid:30738422.

Permin A, Yelifari L, Bloch P, Steenhard N, Hansen N, Nansen P. Parasites in cross-bred pigs in the Upper East Region of Ghana. Vet Parasitol 1999; 87(1): 63-71. http://dx.doi.org/10.1016/S0304-4017(99)00159-4. PMid:10628701.

Pinto JMS, Costa JO, Souza JCA. Ocorrência de endoparasitos em suínos criados em Itabuna, Bahia, Brasil. Ciênc Vet Tróp 2007; 10(2-3): 79-85.

Rajković-Janje R, Bosnić S, Rimac D, Dragičević P, Vinković B. Prevalence of helminths in wild boar from hunting grounds in eastern Croatia. Z Jagdwiss 2002; 48(4): 261-270. http://dx.doi.org/10.1007/BF02189697.

Roepstorff A, Mejer H, Nejsum P, Thamsborg SM. Helminth parasites in pigs: new challenges in pig production and current research highlights. Vet Parasitol 2011; 180(1-2): 72-81. http://dx.doi.org/10.1016/j.vetpar.2011.05.029. PMid:21684689.

Solaymani-Mohammadi S, Mobedi I, Rezaian M, Massoud J, Mohebali M, Hooshyar H, et al. Helminth parasites of the wild boar, Sus scrofa, in Luristan province, western Iran and their public health significance. J Helmintho/ 2003; 77(3): 263-267. http://dx.doi. org/10.1079/JOH2003168. PMid:12895286. 
Stojanov I, Pavlović I, Pušić I, Prodanov-Radulović J, Ratajac R, Marčić D, et al. Determination of endoparasites by faecal examination in the wild boar population in Vojvodina (Serbia). Maced Vet Rev 2018; 41(1): 39-46. http://dx.doi.org/10.1515/macvetrev-2017-0029.

Tamboura HH, Banga-Mboko H, Maes D, Youssao I, Traore A, Bayala B, et al. Prevalence of common gastrointestinal nematode parasites in scavenging pigs of different ages and sexes in Eastern Centre province, Burkina Faso. Onderstepoort J Vet Res 2006; 73(1): 53-60. http://dx.doi.org/10.4102/ojvr.v73i1.169. PMid:16715878.

Thamsborg S, Ketzis J, Horii Y, Matthews JB. Strongyloides spp. infections of veterinary importance. Parasitology 2017; 144(3): 274-284. http://dx.doi.org/10.1017/S0031182016001116. PMid:27374886.

Vicente J, Rodrigues HO, Gomes DC, Pinto RM. Brazilian Nematodes. Part V: nematodes of Mammals. Rev Bras Zoo/ 1997; 14(S1): 1-452. http://dx.doi.org/10.1590/S0101-81751997000500001.

Weng YB, Hu YJ, Li Y, Li BS, Lin RQ, Xie DH, et al. Survey of intestinal parasites in pigs from intensive farms in Guangdong Province, People's Republic of China. Vet Parasito/ 2005; 127(3-4): 333-336. http://dx.doi.org/10.1016/j.vetpar.2004.09.030. PMid:15710534.

Yadav AK, Tandon V. Nematode parasite infections of domestic pigs in a sub-tropical and high-rainfall area of India. Vet Parasitol 1989; 31(2): 133-139. http://dx.doi.org/10.1016/0304-4017(89)90028-9. PMid:2787072. 